\title{
Intercropping of sorghum with Paiaguas palisadegrass in a crop-livestock integration system for pasture recovery
}

\author{
Charles Barbosa Santos ${ }^{1}$, Kátia Aparecida de Pinho Costa*2, Wender Ferreira de Souza ${ }^{2}$, Alessandro Guerra da \\ Silva ${ }^{1}$, Victor Costa e Silva ${ }^{2}$, Itamar Pereira de Oliveira ${ }^{2}$, Eduardo Valcacer Brandstette ${ }^{2}$
}

\author{
${ }^{1}$ University of Rio Verde, College of Agricultural Science, Rio Verde, Goiás, Brazil \\ ${ }^{2}$ Goiano Federal Institute, Graduate Program in Agricultural Sciences and Animal Science, Rio Verde, Goiás, Brazil
}

*Corresponding author: katia.costa@ifgoiano.edu.br

Abstract

Intercropping systems have become an interesting alternative for grain and forage production because they are sustainable systems that reduce carbon emissions in degraded pasture areas. However, few studies have used forage species recently introduced into the market, and more studies that assess the performances of these species in integrated systems are needed. Therefore, the objective of this study was to evaluate the agronomic characteristics of intercropped sorghum and Paiaguas palisadegrass (including the species name) in a crop-livestock integration system for pasture recovery. The field experiment was conducted in the municipality of Rio Verde, Goiás, Brazil, using a randomized block design with four replications. The treatments consisted of the following forage systems: monocropping of sorghum, monocropping of Paiaguas palisadegrass, row intercropping of sorghum with Paiaguas palisadegrass, interrow intercropping of sorghum with Paiaguas palisadegrass and intercropping of sorghum with oversown Paiaguas palisadegrass. To obtain a desired population of 240,000 plants ha ${ }^{-1}, 12$ seeds of sorghum and $5 \mathrm{~kg}$ of viable pure seeds of the forage species were planted per meter and hectare, respectively. The growth of Paiaguas palisadegrass in the same row as sorghum reduced the sorghum grain yield. The intercropping of sorghum with oversown Paiaguas palisadegrass hindered the initial development of Paiaguas palisadegrass in terms of plant height and number of tillers due to shading, and this effect was reflected in the dry mass production. Row and interrow intercropping provided higher dry mass production without affecting the forage quality. Therefore, the interrow intercropping of sorghum with Paiaguas palisadegrass was found to be a promising agricultural technique for grain and forage production that could be used for the establishment of new pastures or pasture recovery.

Keywords: Brachiaria brizantha; Grain yield; Integrated systems; Sorghum bicolor; Tropical forage.

\section{Introduction}

The agricultural sector has been attempting to meet the world's growing demands for grains, meat, milk, wood, fiber and bioenergy. In addition, there is a need to increase productivity without the establishment of new areas or deforestation to expand agricultural frontiers (Cordeiro et al., 2015). In this context, diversifying the land uses in agricultural areas and increasing the efficiency and resilience of production systems can contribute to the harmonization of these interests. The crop-livestock integration system has emerged as a technology for strengthening agribusiness in a path toward sustainability (Vilela et al., 2011). Integrated no-till crop and livestock production systems might help rejuvenate degraded pastures, increase the land use efficiency (LUE), and increase an enterprise's revenue (Crusciol et al., 2014). In addition, this technique was adopted by Brazil to reduce the emission of greenhouse gases based on the National Policy on Climate Change (NPCC) (Silva et al., 2018). The degradation of pastures is one of the biggest problems in Brazilian livestock production and directly affects the sustainability of a production system. The problem becomes apparent in some situations, such as when the stocking rate is less than 1.0 animal units per hectare. However, these livestock production areas show enormous potential for tripling the country's crop and livestock production yields and for meeting the demand for food in a more sustainable manner (Balbinot Junior et al., 2009). Therefore, the crop-livestock integration system has emerged as an alternative for promoting pasture recovery, diversifying areas currently planted with only one type of Brachiaria (Pacheco et al., 2008) and producing forage/straw in the off-season in succession with soybean for maintenance of the no-tillage system (Horvathy Neto et al., 2014; Silva et al., 2014; Borges et al., 2016). This technique also stands out as a sustainable and competitive technology that can help strengthen the Brazilian agribusiness (Almeida et al., 2012). The seeding of annual crops intercropped with tropical forages is an efficient and economically feasible technique that can alter the carbon stocks and the emission of greenhouse gases from the soil to the atmosphere and thereby lead to a 
decrease in global warming and sustainable agricultural and livestock production (Carvalho et al., 2010). Among the annual crops used in integrated systems, sorghum is an excellent choice for the production of grains (Silva et al., 2015a; Silva et al., 2015b), forage (Ribeiro et al., 2015) and silage (Ribeiro et al., 2017), particularly in areas where water deficits and low soil fertility pose greater risks for the cultivation of other crops. In addition to sorghum, Brachiaria species exhibit excellent adaptation to Cerrado (Brazilian savanna) soils, are easily established and contribute to water infiltration and soil aggregation and aeration due to their large root systems (Stumpf et al., 2016). Brachiaria brizantha cv. BRS Paiaguás is one such species, and this grass presents satisfactory results in terms of yield (Costa et al., 2016a; Guarnieri et al., 2019) and greater regrowth during periods of forage shortage. Consequently, this grass leads to greater weight gains per animal and area (Euclides et al., 2016).

Paiaguas palisadegrass is considered an excellent forage for crop-livestock integration because this grass does not affect the development of annual crops (Costa et al., 2016a; Santos et al., 2016), is easily desiccated (Machado and Valle, 2011) and shows a higher forage accumulation rate and good leaf percentages and dry mass yields compared with other forages (Euclides et al., 2016).

Identification of the optimal method for sowing sorghum intercropped with Paiaguas palisadegrass will allow exploration of the use of this species for grain production and forage in the off-season. Therefore, the objective of this study was to evaluate the agronomic characteristics of intercropped sorghum and Paiaguas palisadegrass in a crop-livestock integration system for pasture recovery.

This study was based on the hypothesis that different types of sowing affect the sorghum grain yield and the production and quality of Paiaguas palisadegrass. Integrated production systems positively influence the grain yields, and the harvesting of the area induces pasture recovery.

Results

\section{Agronomic characteristics of sorghum}

An analysis of variance showed that the forage systems had no significant effect ( $p>0.05$ ) on the plant height at 30,60 and 90 days after sowing (DAS), the plant population size at 30 and 90 DAS, the final stalk diameter, the panicle length, the final population size, the number of grains per panicle and the 1000 -grain weight. However, the forage systems exerted an effect $(p<0.05)$ on the plant population size and stem diameter at 60 DAS (Table 1), the final plant height (Table 2), the plant population size and stem diameter at 60 DAS (Table 1 ) and the grain yield (Table 2 ). The lowest values for the plant population and stem diameter at 60 DAS were obtained with the row intercropping of sorghum with Paiaguas palisadegrass (Table 1). In addition to this last variable, the interrow system provided results that were similar to those obtained with sorghum monocropping but yielded values that were higher than those obtained with the other treatments. The evaluation of the grain yield indicated that the lowest yield was obtained with the row intercropping of sorghum with Paiaguas palisadegrass (Table 2). However, no significant differences in grain yield $(p>0.05)$ were found among the interrow and oversown intercropping systems and the sorghum monocropping system.

\section{Forage production and quality}

The evaluation of the characteristics of Paiaguas palisadegrass revealed significant differences $(p<0.05)$ in the plant height at 30 and 60 DAS and the number of tillers at 30, 60 and 90 DAS (Table 3). The row and interrow intercropping of sorghum with Paiaguas palisadegrass yielded the highest plant heights at 30 and 60 DAS. In contrast, this trend was not obtained with the oversown intercropping system, which yielded the lowest values, similar to those obtained with the Paiaguas palisadegrass monocropping system (Table 3 ).

The lowest number of tillers at 30 DAS was obtained with the oversown intercropping system. The numbers of tillers 60 and 90 DAS obtained with the row and interrow intercropping systems were similar to each other but lower than those obtained with the oversown intercropping system and the Paiaguas palisadegrass monocropping systems, which yielded larger numbers of tillers (Table 3 ).

The analysis of the productive characteristics of Paiaguas palisadegrass at the time of sorghum harvest (first cut) and at the time of the second and third cuttings showed significant differences $(p>0.05)$ between the forage systems with respect to various production variables, namely the dry mass, plant height, leaf blade-to-stem ratio and number of tillers (Table 4). The lowest dry production yield at the time of the first cutting was obtained with the intercropping of sorghum with oversown Paiaguas palisadegrass (Table 4). At the time of the other cuttings, no significant differences $(p>0.05)$ were observed between the forage systems. The analysis of the different cuttings revealed that significantly higher production $(p<0.05)$ was obtained at the time of the first cutting compared with the times of the other cuttings. The intercropping of sorghum with oversown Paiaguas palisadegrass resulted in the lowest plant height. However, similar plant heights were obtained with the row and interrow intercropping systems and the Paiaguas palisadegrass monocropping system $(p>0.05)$. The comparison of the cuttings revealed that the highest plant height was detected at the time of the first cutting, and this finding was obtained with all tested forage systems. The highest leaf blade-to-stem ratio was obtained with the Paiaguas palisadegrass monocropping system, and this value significantly differed $(p<0.05)$ from those obtained with the intercropping systems. The oversown intercropping system yielded a lower value for this variable at the time of the second cutting, whereas similar values were obtained among the various forage systems at the time of the third cutting $(p>0.05)$ (Table 4). The analysis of the various cuttings showed that similar leaf blade-to-stem ratios were obtained at the times of the first and second cuttings with the Paiaguas palisadegrass monocropping system and that this value was higher than that obtained at the time of the third cutting. For the row and interrow systems, only the first cut differed from the other cuts. In the oversown system, no significant difference ( $p>0.05$ ) between cuts was observed. The row and oversown intercropping systems yielded lower numbers of tillers at the times of the first and second cuttings. The forage systems had no effect on this variable at the time of the third cutting, as demonstrated by the finding that similar values were obtained 
for this variable with all tested forage systems $(p>0.05)$. Moreover, no significant differences $(p>0.05)$ in the numbers of tillers at the various cutting times were obtained between the forage systems (Table 4).

The analysis of forage quality showed no significant differences ( $p>0.05)$ in the CP levels between the forage systems at the three cutting times (Table 5). The comparison of the cuttings showed that a lower CP was obtained at the time of the first cutting and that this value differed from those obtained at the time of the second and third cuttings, at which time similar values were obtained.

The forage systems did not affect $(p>0.05)$ the NDF, ADF or DMDIV at any cutting time (Table 5). However, the comparison of the cuttings showed that higher fiber content and consequently a lower DMDIV were detected at the time of the first cutting, and this finding was obtained for all tested systems.

\section{Discussion}

The forage system did not have an effect on the plant height at 30,60 and 90 DAS or on the plant population size at 30 and 90 DAS. The faster emergence of sorghum compared with Paiaguas palisadegrass contributed to the lack of an effect on the height and population size of the sorghum plants in all sowing systems (Table 1). In addition, the shading caused by the taller sorghum plants at the initial phase of development suppressed the growth of Paiaguas palisadegrass.

The lower values obtained for the plant population size and stem diameter at 60 DAS with the row intercropping of sorghum with Paiaguas palisadegrass might be due to greater competition between the species. High growth and stem elongation rates were obtained from the initiation of floral differentiation of sorghum until flowering (reproductive phase). The lack of water, light and nutrients at this stage directly affects the development of sorghum, and this effect is accentuated by the simultaneous cultivation of two species in the area.

However, the difference in stem diameter at 60 DAS was not observed at the time of sorghum harvest, which demonstrated that the plants have the ability to recover from their competition with other plants in the intercropped system. The stem is a reserve storage structure, and a larger diameter reflects a greater storage capacity for photoassimilates. Therefore, larger diameters contribute considerably to grain filling and thus to increases I $n$ the grain yield (Gimenes et al., 2008).

Through an evaluation of the row and interrow intercropping of sorghum with various cultivars of Brachiaria brizantha (Marandu palisadegrass, Xaraes palisadegrass and Piata palisadegrass), Ribeiro et al. (2015) found that only the row intercropping system with Xaraes palisadegrass decreased the stem diameter of sorghum plants. In the same study, interrow sowing generated less competition with the sorghum plants, which demonstrated the viability of interrow intercropping.

The same trend was observed with the final plant height. Row intercropping with Paiaguas palisadegrass reduced the height of the sorghum plants (Table 2) due to greater competition for water, light, nutrients and physical space between the sorghum and Paiaguas palisadegrass plants. These effects resulted in decreases in the development of the plants, stem diameter, population size and final plant height.

Importantly, the plant population size is an important variable for determining the sorghum crop yield. This measure is especially important when using early cultivars, such as Buster, because these variables exhibit an inverse relationship. In turn, a higher stem diameter is related to greater tolerance to the lodging of sorghum plants, which is an undesirable characteristic at the time of harvest due to higher grain losses (Silva et al., 2013).

The lower sorghum grain yield obtained with the row intercropping system was associated with competition between plant species, similar to the results found for the final plant height. This finding also demonstrates the effect of competition between species when these are sown in the same row. Although Paiaguas palisadegrass was sown at a depth of $6 \mathrm{~cm}$, it still affected the development of sorghum because the sowing of Paiaguas palisadegrass was conducted during a period that provided good water availability and adequate temperatures for the development of both species (Figure 1). In addition, the forage grass has a deep fasciculated root system, which, when combined with good water and nutrient availability in soil, favors plant development (Costa et al., 2016b). For an intercropping system of sorghum with Brachiaria ruziziensis, Borges et al. (2016) also found that sowing the grass in the same row decreased the sorghum grain yield.

The beneficial effects of the weather conditions provided by early sowing can be observed in the sorghum grain yield. Although inter-species competition was observed, the sorghum grain yield obtained in this study was higher than those obtained in other studies with the same crops performed in the Center-West region (Horvathy Neto et al., 2012; Silva et al., 2013; Silva et al., 2014).

The lack of significant differences in the grain yield between the sorghum monocropping system and the interrow and oversown intercropping systems confirm that these sowing strategies are promising for increasing grain production (Table 2 ). In some cases, the consortium increases the sorghum grain yield, as observed by Borghi et al. (2013). These results indicate that the association of the Buster hybrid with Paiaguas palisadegrass is feasible for cultivation of the second crop. In this study, the forage did not induce a reduction in the grain yield.

The higher plant heights of Paiaguas palisadegrass at 30 and 60 DAS obtained with the row and interrow intercropping systems were due to the effect of shading produced by the sorghum plants, which caused etiolation of the plants. A similar effect was reported by Horvathy Neto et al. (2012), who found that the intercropping of sorghum with Brachiaria brizantha cv. Marandu and Brachiaria ruziziensis provided taller plants compared with those obtained with the corresponding monocropping systems.

The lower number of tillers at 30 DAS obtained with the oversown intercropping system can be explained by the shading caused by the taller sorghum plants (Table 3 ). The decrease in solar radiation caused by the sorghum plants in the intercropping systems reduces the amount of incident radiation on the basal third of the plants and thereby suppresses the formation of tillers in the axillary buds of the Brachiaria plants (Soares et al., 2009). 
Table 1. Mean plant height, plant population size and stem diameter of sorghum at 30, 60 and 90 days after sowing (DAS; corresponding to the vegetative, reproductive and maturation stages, respectively) in the monocropping system and various intercropping systems with Paiaguas palisadegrass.

\begin{tabular}{|c|c|c|c|c|}
\hline \multirow[t]{2}{*}{ Forage systems } & \multicolumn{4}{|l|}{ DAS } \\
\hline & 30 & 60 & \multicolumn{2}{|l|}{90} \\
\hline & \multicolumn{4}{|c|}{ Plant height $(\mathrm{cm})$} \\
\hline Sorghum monocropping & 60.30 & 89.75 & \multicolumn{2}{|l|}{92.57} \\
\hline Sorghum x Paiaguas palisadegrass in rows & 58.00 & 88.00 & \multicolumn{2}{|l|}{92.37} \\
\hline Sorghum $x$ Paiaguas palisadegrass in inter rows & 59.00 & 83.00 & \multicolumn{2}{|l|}{98.45} \\
\hline Sorghum x Paiaguas palisadegrass oversown & 60.25 & 92.25 & \multicolumn{2}{|l|}{88.37} \\
\hline Mean & 59.39 & 88.25 & \multicolumn{2}{|l|}{92.94} \\
\hline \multirow[t]{2}{*}{ CV (\%) } & 2.67 & 8.98 & 2.67 & \\
\hline & \multicolumn{4}{|c|}{ Population size (plants ha ${ }^{-1}$ ) } \\
\hline Sorghum monocropping & 172.00 & $165.00 \mathrm{a}$ & \multicolumn{2}{|l|}{160.00} \\
\hline Sorghum x Paiaguas palisadegrass in rows & 170.00 & $154.00 \mathrm{~b}$ & \multicolumn{2}{|l|}{150.00} \\
\hline Sorghum $x$ Paiaguas palisadegrass in inter rows & 175.00 & $170.00 \mathrm{a}$ & \multicolumn{2}{|l|}{150.00} \\
\hline Sorghum $x$ Paiaguas palisadegrass oversown & 180.00 & $165.00 \mathrm{a}$ & \multicolumn{2}{|l|}{145.00} \\
\hline Mean & 174.25 & 163.50 & \multicolumn{2}{|l|}{151.25} \\
\hline \multirow[t]{2}{*}{ CV (\%) } & 11.74 & 7.22 & 11.74 & \\
\hline & \multicolumn{4}{|c|}{ Stem diameter $(\mathrm{mm})$} \\
\hline Sorghum monocropping & 18.73 & $22.99 \mathrm{a}$ & & 15.72 \\
\hline Sorghum $x$ Paiaguas palisadegrass in rows & 17.03 & $19.50 \mathrm{~b}$ & & 16.30 \\
\hline Sorghum $x$ Paiaguas palisadegrass in inter rows & 19.11 & $21.20 \mathrm{a}$ & & 16.20 \\
\hline Sorghum x Paiaguas palisadegrass oversown & 17.18 & $18.91 \mathrm{~b}$ & & 15.12 \\
\hline Mean & 18.01 & 20.65 & & 15.83 \\
\hline CV (\%) & 7.44 & 7.28 & & 7.44 \\
\hline
\end{tabular}

Means followed by different letters in the same column differ from each other, as demonstrated by Tukey's test at $5 \%$ probability.

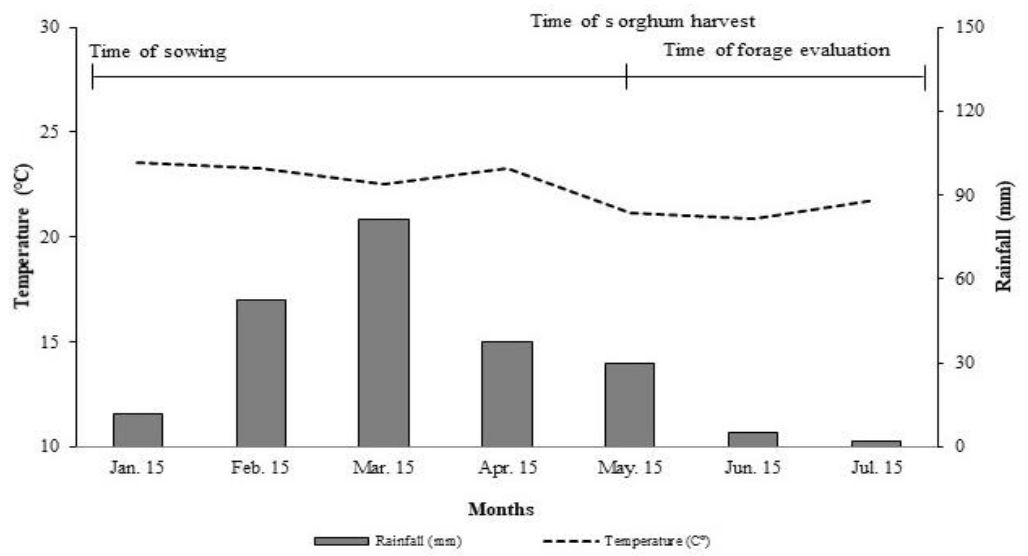

Fig 1. Rainfall and mean temperatures in Rio Verde, Goiás, Brazil, from January to July 2015.

Table 2. Mean final plant height (FPH), final stem diameter (FSD), panicle diameter (PD), panicle length (PL), final population size (FPS), number of grains per panicle (NGP), 1000-grain weight (TGW) and grain yield (YIELD) of sorghum in different forage systems.

\begin{tabular}{|c|c|c|c|}
\hline Forage systems & $\mathrm{FPH}(\mathrm{cm})$ & FSD (m) & $\mathrm{PD}(\mathrm{mm})$ \\
\hline Sorghum monocropping & $91.80 \mathrm{a}$ & 16.02 & 63.47 \\
\hline Sorghum $x$ Paiaguas palisadegrass in rows & $86.80 \mathrm{~b}$ & 15.30 & 53.42 \\
\hline Sorghum $\times$ Paiaguas palisadegrass in inter rows & $93.90 \mathrm{a}$ & 14.65 & 54.47 \\
\hline Sorghum x Paiaguas palisadegrass oversown & $88.45 b$ & 16.52 & 58.92 \\
\hline Mean & 89.99 & 15.62 & 57.57 \\
\hline \multirow[t]{2}{*}{ CV (\%) } & 3.48 & 8.60 & 10.45 \\
\hline & $\mathrm{PL}(\mathrm{cm})$ & $\begin{array}{c}\text { FPS } \\
\left(\text { plants ha }^{-1}\right)\end{array}$ & NGP \\
\hline Sorghum monocropping & 27.70 & 160.00 & 12.62 \\
\hline Sorghum $x$ Paiaguas palisadegrass in rows & 27.05 & 150.00 & 9.37 \\
\hline Sorghum $x$ Paiaguas palisadegrass in inter rows & 26.60 & 150.00 & 8.75 \\
\hline Sorghum x Paiaguas palisadegrass oversown & 27.10 & 145.00 & 12.37 \\
\hline Mean & 27.11 & 151.25 & 10.77 \\
\hline \multirow[t]{2}{*}{ CV (\%) } & 7.39 & 7.34 & 25.87 \\
\hline & TGW (g) & \multicolumn{2}{|r|}{ YIELD $\left(\mathrm{kg} \mathrm{ha}^{-1}\right)$} \\
\hline Sorghum monocropping & 28.50 & \multicolumn{2}{|r|}{$6,219 a$} \\
\hline Sorghum $\times$ Paiaguas palisadegrass in rows & 24,20 & \multicolumn{2}{|r|}{$4,598 \mathrm{~b}$} \\
\hline Sorghum $x$ Paiaguas palisadegrass in inter rows & 29.24 & \multicolumn{2}{|r|}{$6,241 \mathrm{a}$} \\
\hline Sorghum x Paiaguas palisadegrass oversown & 26.36 & \multicolumn{2}{|r|}{5,746 a } \\
\hline Mean & 27.07 & \multicolumn{2}{|r|}{5,701} \\
\hline CV (\%) & 11.30 & \multicolumn{2}{|r|}{6.43} \\
\hline
\end{tabular}


Table 3. Mean plant height and number of tillers of Paiaguas palisadegrass at 30,60 and 90 days after sowing (DAS) in monocropping and various intercropping systems with sorghum.

\begin{tabular}{lccc}
\hline Forage systems & 30 DAS & $\begin{array}{c}60 \text { DAS } \\
\text { Plant height (cm) }\end{array}$ & 90 DAS \\
\hline Paiaguas palisadegrass monocropping & $24.25 \mathrm{ab}$ & $86.25 \mathrm{~b}$ & 88.62 \\
Sorghum x Paiaguas palisadegrass in rows & $29.00 \mathrm{a}$ & $92.50 \mathrm{a}$ & 109.82 \\
Sorghum x Paiaguas palisadegrass in inter rows & $28.50 \mathrm{a}$ & $96.50 \mathrm{a}$ & 111.52 \\
Sorghum x Paiaguas palisadegrass oversown & $18.25 \mathrm{~b}$ & $42.00 \mathrm{c}$ & 99.77 \\
CV (\%) & 13.60 & 7.38 & 14.32 \\
\hline & & Number of tillers (m) & $108.25 \mathrm{a}$ \\
Paiaguas palisadegrass monocropping & $54.25 \mathrm{a}$ & $80.25 \mathrm{a}$ & $84.00 \mathrm{~b}$ \\
Sorghum x Paiaguas palisadegrass in rows & $48.00 \mathrm{a}$ & $54.75 \mathrm{~b}$ & $83.25 \mathrm{~b}$ \\
Sorghum x Paiaguas palisadegrass in inter rows & $47.75 \mathrm{a}$ & $54.25 \mathrm{~b}$ & $54.25 \mathrm{c}$ \\
Sorghum x Paiaguas palisadegrass oversown & $30.00 \mathrm{~b}$ & $40.75 \mathrm{c}$ & 19.31 \\
CV (\%) & 16.38 & 25.74 &
\end{tabular}

Table 4. Dry mass production, plant height, leaf blade-to-stem ratio and number of tillers of Paiaguas palisadegrass in the different forage systems and various cutting times.

\begin{tabular}{|c|c|c|c|}
\hline \multirow[t]{2}{*}{ Forage systems } & $1^{\text {st }}$ cut & $2^{\text {nd }}$ cut & $3^{\text {rd }}$ cut \\
\hline & \multicolumn{3}{|c|}{ Dry mass production $\left(\mathrm{kg} \mathrm{ha}^{1}\right)$} \\
\hline Paiaguas palisadegrass monocropping & $5000 \mathrm{Aa}$ & $3970 \mathrm{Ab}$ & $3130 \mathrm{Ab}$ \\
\hline Sorghum $\times$ Paiaguas palisadegrass in rows & 5340 Аа & $3800 \mathrm{Ab}$ & $2930 \mathrm{Ab}$ \\
\hline Sorghum $\times$ Paiaguas palisadegrass in inter rows & 5040 Аа & $4320 \mathrm{Aab}$ & $3480 \mathrm{Ab}$ \\
\hline Sorghum $\times$ Paiaguas palisadegrass oversown & $3390 \mathrm{Ba}$ & $4320 \mathrm{Aa}$ & $2750 \mathrm{Aa}$ \\
\hline \multirow[t]{2}{*}{ CV (\%) } & & 20.06 & \\
\hline & \multicolumn{3}{|c|}{ Plant height $(\mathrm{cm})$} \\
\hline Paiaguas palisadegrass monocropping & 89.85 Аа & $66.70 \mathrm{Ab}$ & $50.5 \mathrm{Ac}$ \\
\hline Sorghum $\times$ Paiaguas palisadegrass in rows & $86.55 \mathrm{Aa}$ & $67.05 \mathrm{Ab}$ & $53.20 \mathrm{Ac}$ \\
\hline Sorghum $\times$ Paiaguas palisadegrass in inter rows & $80.85 \mathrm{Aa}$ & $68.05 \mathrm{Ab}$ & $51.15 \mathrm{Ac}$ \\
\hline Sorghum $\times$ Paiaguas palisadegrass oversown & $69.60 \mathrm{Ba}$ & $50.76 \mathrm{Bb}$ & $38.35 \mathrm{Bc}$ \\
\hline \multirow[t]{2}{*}{ CV (\%) } & & 11.22 & \\
\hline & \multicolumn{3}{|c|}{ Leaf blade-to-stem ratio } \\
\hline Paiaguas palisadegrass monocropping & 2.07 Aa & $2.20 \mathrm{Aa}$ & $1.19 \mathrm{Ab}$ \\
\hline Sorghum $\times$ Paiaguas palisadegrass in rows & $1.82 \mathrm{Ba}$ & $1.26 \mathrm{Bb}$ & $1.10 \mathrm{Ab}$ \\
\hline Sorghum $\times$ Paiaguas palisadegrass in inter rows & $1.90 \mathrm{Ba}$ & $1.50 \mathrm{Bab}$ & $1.21 \mathrm{Ab}$ \\
\hline Sorghum $\times$ Paiaguas palisadegrass oversown & $1.15 \mathrm{Ba}$ & $0.93 \mathrm{Ca}$ & 0.99 Аа \\
\hline \multirow[t]{2}{*}{$\mathrm{CV}(\%)$} & & 20.16 & \\
\hline & \multicolumn{3}{|c|}{ Number of tillers (m) } \\
\hline Paiaguas palisadegrass monocropping & $207.25 \mathrm{Aa}$ & $231.00 \mathrm{Aa}$ & $189.50 \mathrm{Aa}$ \\
\hline Sorghum $\times$ Paiaguas palisadegrass in rows & $161.00 \mathrm{Ba}$ & $169.50 \mathrm{Ba}$ & $180.25 \mathrm{Aa}$ \\
\hline Sorghum $\times$ Paiaguas palisadegrass in inter rows & 185.50 Aba & $215.50 \mathrm{Aa}$ & $186.50 \mathrm{Aa}$ \\
\hline Sorghum $\times$ Paiaguas palisadegrass oversown & $157.25 \mathrm{Ba}$ & $147.00 \mathrm{Ba}$ & $173.75 \mathrm{Aa}$ \\
\hline $\mathrm{CV}(\%)$ & \multicolumn{3}{|c|}{16.81} \\
\hline
\end{tabular}

Table 5. Crude protein (CP), neutral detergent fiber (NDF), acid detergent fiber (ADF) and in vitro dry matter digestibility (DMDIV) of Paiaguas palisadegrass in the different monocropping and intercropping forage systems and various cutting times.

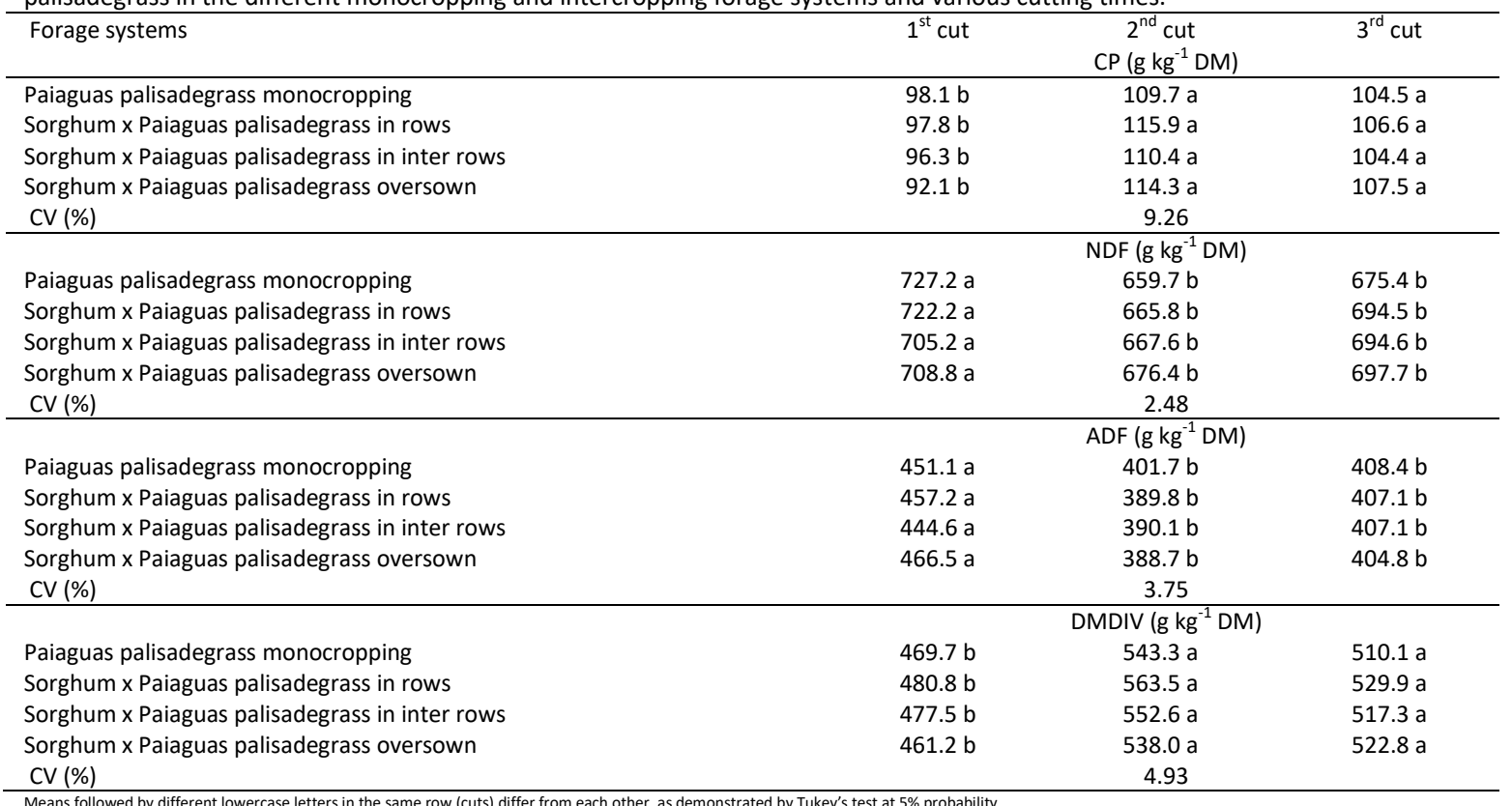


Conversely, the higher number of tillers at 60 and 90 DAS observed with the Paiaguas palisadegrass monocropping system was due to the higher light incidence on the basal portion of the plants compared with that observed with the intercropping systems. This increase favors the sprouting of new lateral buds, which resulted in the generation of new tillers.

The lower dry matter production at the time of the first cutting obtained with the intercropping of sorghum with oversown Paiaguas palisadegrass (Table 4) was due to the 15-day delay in the sowing of this forage system. This result proves that only this sowing strategy does not contribute to the good development of the forage. In contrast, the row and interrow intercropping of sorghum with Paiaguas palisadegrass was advantageous because these systems did not affect the dry mass production of Paiaguas palisadegrass.

The production of forage in the off-season obtained by cutting the forage is of0 paramount importance for animal feed. At the time of the first cutting (May 5), forages commonly exhibit decreased growth in Central Brazil due to the lower availability of water in the region. This decrease leads to a low availability of forage, which affects animal performance. Hence, intercropping is important because it provides forage in addition to grains.

The higher dry mass production at the time of the first cutting obtained with the Paiaguas palisadegrass monocropping system is attributed to the free growth of the plants until the first cut is made. In crop-livestock integration systems, the area is used for forage production after the grain harvesting, as highlighted by Vilela et al. (2011). Paiaguas palisadegrass presented satisfactory dry mass production (4.146 and 3.053 $\mathrm{kg} \mathrm{ha}^{-1}$ at the time of the second and third cuttings, respectively) even during periods of low rainfall (Figure 1) after the sorghum harvest, which are common in the Central-West region. This result indicates that the simultaneous growth of annual and forage crops in the same area can be viable for forage production in addition to reducing the cost of pasture establishment.

The highest leaf blade-to-stem ratio was obtained with the Paiaguas palisadegrass monocropping system, and this finding was due to the free growth of the plants in this cultivation system, which allowed greater elongation of the leaf blades (Table 4). The higher ratio obtained with the Paiaguas palisadegrass monocropping system at the time of the first and second cuttings was associated with the greater development of forage during these periods, which allowed the plants to develop a leaves with a greater area relative to the stem size. The absence of significant differences in the bromatological variables (CP, NDF, ADF and DMDIV) between the different forage systems shows that Paiaguas palisadegrass can be intercropped with sorghum in different sowing systems without hindering forage development and demonstrates the viability of using this grass in intercropping systems.

The lower crude protein levels detected at the time of the first cutting are associated with the faster growth of Paiaguas palisadegrass from sowing to sorghum harvest, and this growth results in a greater leaf blade-to-stem ratio. During this period, the forage was allowed to grow freely, which increased the number of stems and thus the dry mass. These increases negatively influenced the forage quality due to a decrease in the crude protein content, which would result in a decrease in the dry matter intake by animals.

The crude protein content in forage is important because ruminal cellulolytic bacteria undergo satisfactory development if the content is equal to or greater than $70 \mathrm{~g} \mathrm{~kg}^{-1}$ (Van Soest, 1994), and the levels in Paiaguas palisadegrass obtained in all forage systems met these nutritional requirements.

The lower fiber fraction and higher in vitro dry matter digestibility at the time of the second and third cuttings (Table 5) relative to those at the time of the first cutting could be explained by the shorter development time of the grass ( 28 days). This result is associated with changes in the chemical composition of the fraction, which showed decreases in the neutral and acid detergent fiber contents.

In addition, Paiaguas palisadegrass was allowed to grow freely for more than 100 days. When Paiaguas palisadegrass was cut after sorghum harvest, new tillers were formed. This growth provided better forage quality, even during periods with low rainfall, and this finding shows the potential of using Paiaguas palisadegrass for producing forage under these conditions.

The results obtained with the three cuttings of the forage showed that the intercropping of sorghum with Paiaguas palisadegrass could be considered an excellent alternative strategy for supplying food in the off-season. Additionally, we need to emphasize the importance of intercropping systems for pasture establishment. The pasture that is obtained after an annual crop is harvested can be used in the off-season, which is a period characterized by low forage availability due to low water availability in the region.

This study demonstrates the importance of crop-livestock integration systems for grain production and new pasture establishment. In addition, the system provides increased land use, a higher agricultural efficiency, greater soil carbon fixation and reduced greenhouse gas emissions from soil to the atmosphere (Carvalho et al., 2010). These findings support the need to adopt sustainable agricultural systems for food production (Vilela et al., 2011). Other studies have shown the viability of crop-livestock integration systems as a promising agricultural technique for the production of grains and forage with good nutritive values in the Central-West region of Brazil (Silva et al., 2014; Borges et al., 2016; Costa et al., 2016; Santos et al., 2016; Silva et al., 2017; Guarnieri et al., 2019).

\section{Materials and methods}

\section{Site description}

The experiment was conducted in the livestock production sector of the Goiano Federal Institute, Rio Verde Campus (altitude of $748 \mathrm{~m}, 17^{\circ} 48^{\prime} \mathrm{S}$ and $050^{\circ} 55^{\prime} \mathrm{W}$ ). The study area was planted with Brachiaria brizantha cv. Marandu over 40 years prior to the study and was at an advanced stage of degradation. During the experiment, the precipitation and mean monthly temperature data were monitored daily (Figure 1).

The soil was classified as distroferric Red Latosol (Embrapa, 2013). Soil samples were collected at a depth of $0-20 \mathrm{~cm}$ to determine the physicochemical characteristics of the soil in the experimental area prior to establishment of the forage systems, and the following results were obtained from the analysis of the samples: $500 \mathrm{~g} \mathrm{~kg}^{-1}$ clay, $220 \mathrm{~g} \mathrm{~kg}^{-1}$ silt, $280 \mathrm{~g} \mathrm{~kg}^{-}$ 
${ }^{1}$ sand, $\mathrm{pH}\left(\mathrm{CaCl}_{2}\right)$ : 5,51; Ca: 2,20 (cmol $\left.\mathrm{cm}^{-3}\right) ; \mathrm{Mg}: 0,91\left(\mathrm{cmol}_{\mathrm{c}}\right.$ $\left.\mathrm{dm}^{-3}\right)$; Al: 0,01 $\left(\mathrm{cmol}_{\mathrm{c}} \mathrm{dm}^{-3}\right) ; \mathrm{Al}+\mathrm{H}: 3,30\left(\mathrm{cmol}_{\mathrm{c}} \mathrm{dm}^{-3}\right) ; \mathrm{K}_{2} \mathrm{O}: 0,09$ $\left(\mathrm{cmol}_{\mathrm{c}} \mathrm{dm}^{-3}\right)$; CTC: 6,51 ( $\left.\mathrm{cmol}_{\mathrm{c}} \mathrm{dm}^{-3}\right)$; P (mehlich): 0,34 $\mathrm{mg} \mathrm{dm}^{-3}$; Cu: $2,2 \mathrm{mg} \mathrm{dm}^{-3}$; Zn: 0,4 mg dm${ }^{-3}$; Fe: $14,4 \mathrm{mg} \mathrm{dm}^{-3}$; O.M. 28,70 $\mathrm{g} \mathrm{kg}^{-1}$.

The area was prepared by desiccating the previous crop (Brachiaria) through application of the herbicide Transorb $\left(2.058 \mathrm{~g} \mathrm{a.i.} \mathrm{ha}^{-1}\right)$ at a rate of $150 \mathrm{~L} \mathrm{ha}^{-1}$. Thirty days after desiccation, harrowing was performed in the experimental area using a disk harrow followed by a run with a leveling harrow.

\section{Experimental design and treatments}

The experimental design was a randomized block design with four replications. The treatments consisted of the following forage systems: sorghum monocropping, Paiaguas palisadegrass monocropping, row intercropping of sorghum with Paiaguas palisadegrass, interrow intercropping of sorghum with Paiaguas palisadegrass and intercropping of sorghum with oversown Paiaguas palisadegrass.

The sorghum hybrid Buster (super-early, small-sized red grains without tannins) was used in this study. Each plot had an area of $1042 \mathrm{~m}^{2}$ and was divided into 20 enclosures by an electric fence.

\section{Crop management}

Sowing of the forage systems was performed mechanically on January 24,2015 . The soil was fertilized with $240 \mathrm{~kg} \mathrm{ha}^{-1} \mathrm{P}_{2} \mathrm{O}_{5}$ and $20 \mathrm{~kg} \mathrm{ha}^{-1}$ FTE BR 20 using single superphosphate and frits as the sources, respectively.

In the monocropping and intercropping systems, sorghum was sown at a depth of $3 \mathrm{~cm}$, and in the monocropping system, Paiaguas palisadegrass was sown at the same depth. In the row intercropping system, the Paiaguas palisadegrass was sown at a depth of $6 \mathrm{~cm}$, and in the interrow intercropping system, the grass was sown $0.25 \mathrm{~m}$ from the sorghum row and at a depth of $6 \mathrm{~cm}$. In the oversown intercropping system, the grass was sown 15 days after the sorghum was sown, at a distance of $0.25 \mathrm{~m}$ between the rows and at a depth of $3 \mathrm{~cm}$. To obtain a desired population of 240,000 plants ha ${ }^{-1}, 12$ seeds of sorghum and $5 \mathrm{~kg}$ of viable pure seeds of the forage species were planted per meter and hectare, respectively. At 15 DAS, $80 \mathrm{~kg} \mathrm{ha}^{-1}$ nitrogen and $40 \mathrm{~kg} \mathrm{ha}^{-1} \mathrm{~K}_{2} \mathrm{O}$ were applied by broadcasting using urea and potassium chloride as the sources, respectively.

For weed control during the postemergence period, manual weeding was performed weekly until 50 DAS. The fall armyworm (Spodoptera frugiperda) was controlled through two applications of the insecticides chlorpyrifos $\left(1.0 \mathrm{~L} \mathrm{ha}^{-1} ; 480\right.$ g a.i. ha $\left.{ }^{-1}\right)$ and teflubenzuron $\left(0.050 \mathrm{~L} \mathrm{ha}^{-1} ; 7.5 \mathrm{~g} \mathrm{a.i.} \mathrm{ha}^{-1}\right)$ at 17 $(02 / 10 / 2015)$ and 30 DAS (03/12/2015). Fungi were controlled via the application of the fungicides azoxystrobin + cyproconazole ( $0.50 \mathrm{~L} \mathrm{ha}^{-1} ; 100+40 \mathrm{~g}$ a.i. ha ${ }^{-1}$, respectively).

\section{Evaluation of agronomic characteristics of sorghum}

The following agronomic characteristics of the sorghum crops were measured at 30,60 and 90 DAS during its development (these time points were used to characterize the vegetative, reproductive and maturation stages of the crop, respectively): plant height (measured from the ground to the end of the panicle in 10 randomly selected plants), plant population size (count of the total number of plants per meter transformed into $\mathrm{ha}^{-1}$ ) and stem diameter (measurement of the stem diameter of 10 plants using a digital caliper).

Sorghum was harvested on May 5, 2015. Subsequently, topdressing fertilization was performed in all forage systems through the application of $80 \mathrm{~kg} \mathrm{ha}^{-1}$ nitrogen and $30 \mathrm{~kg} \mathrm{ha}^{-1}$ $\mathrm{K}_{2} \mathrm{O}$ using urea and potassium chloride as the sources, respectively.

At the time of sorghum harvest, the following productive characteristics were evaluated: panicle length (measurement of the length of 10 panicles), panicle diameter (measurement of the median diameter of the panicle in 10 plants), number of grains per panicle (threshing of the grains and subsequent counting), 100-grain weight (weight of a 1000 grains randomly selected from the yield sample with $13 \%$ moisture correction) and grain yield (weight and threshing of the grains with $13 \%$ moisture correction and conversion to $\mathrm{kg} \mathrm{ha}^{-1}$ ).

\section{Evaluation of forage production and quality}

The plant height (measured from the base of the plants to the receptacle in ten randomly chosen plants) and number of tillers (count of the number of tillers per $\mathrm{m}^{2}$ ) of Paiaguas palisadegrass was evaluated at 30,60 and 90 DAS (02/24/2015, 03/24/2015 and 04/23/2015, respectively).

The dry mass production and forage quality of Paiaguas palisadegrass were evaluated after the first cutting of the grass on $05 / 05 / 2015$ (time of sorghum harvest) at the times of the second and third cuttings (06/03/2015 and 06/31/2015, respectively).

A chemical analysis was performed to determine the following variables: dry matter (DM); crude protein (CP), which was obtained through determination of total $\mathrm{N}$ using the microKjeldahl technique and the fixed conversion factor (6.25); neutral detergent fiber (NDF), which was determined according to Mertens (2002); acid detergent fiber (ADF) (AOAC, 1990); and mineral matter (MM). For assessment of the in vitro dry matter digestibility (IVDMD), we used the technique described by Tilley and Terry (1963), which was adapted for artificial rumen by ANKON $^{\circledR}$ using the Daisy incubator manufactured by Ankom Technology.

After evaluation of the cuttings, Paiaguas palisadegrass was allowed to regrow and desiccate for the formation of biomass for soybean planting during the next crop season.

Statistical analysis

The variables were subjected to analysis of variance using the R program version R-3.1.1 (2014) with the ExpDes package (Ferreira et al., 2011). The means were compared by Tukey's test at $5 \%$ probability. To evaluate the forage at different seasons during the year, analyses were conducted using a model of repeated measures over time.

\section{Conclusion}

The cultivation of Paiaguas palisadegrass in the same sowing row as sorghum reduced the sorghum grain yield. The intercropping of sorghum with oversown Paiaguas palisadegrass suppressed the initial development of Paiaguas 
palisadegrass in terms of plant height and number of tillers as a result of shading and consequently affected the production of dry mass.

The row and interrow intercropping with Paiaguas palisadegrass provided greater dry mass production without affecting the forage quality.

Therefore, the interrow intercropping of sorghum with Paiaguas palisadegrass was found to be a promising agricultural technique for grain and forage production that could be used for the establishment of new pastures or pasture recovery.

\section{Acknowledgements}

The authors thank the Goiano Federal Institute for the support provided during the study and the National Council for Scientific and Technological Development (CNPq) and the Goiás Research Foundation (FAPEG) for funding the study.

\section{References}

Almeida CM, Lana AMQ, Rodrigues JAS, Alvarenga RC, Borges I (2012) Influência do tipo de semeadura na produtividade do consórcio Sorgo - Urochloa brizantha cv. Marandu no sistema de Integração Lavoura-Pecuária. Rev Bras Milho Sorgo. 11(1): 60-68.

Association of Official Analytical Chemists - AOAC (1990) Official methods of analysis (15 ed), Washington DC: 1298.

Balbinot Júnior AA, Moraes A, Veiga M, Pelissari A, Dieckow J (2009) Integração lavoura-pecuária: intensificação de uso de áreas agrícolas. Cienc Rural. 39 (6): 1925-1933.

Borges LP, Silva AG, Goulart MMP, Teixeira IR, Simon GA, Costa KAP (2016) Seeding density of Brachiaria ruziziensis intercropped with grain sorghum and effects on soybean in succession. Afr J Agric Res. 11(43): 4343 - 4353.

Borghi E, Crusciol CAC, Nascente AS, Sousa VV, Martins PO, Mateus G, Costa C (2013) Sorghum grain yield, forage biomass production and revenue as affected by intercropping time. Eur J Agron. 51: 130 -139.

Carvalho JLN, Avanzi JC, Silva MLN, Mello CR, Cerri CEP (2010) Potencial de sequestro de carbono em diferentes biomas do Brasil. Rev Bras Cienc Solo. 34(2): 277 - 289.

Cordeiro LAM, Volela L, Marchão RL, Kluthcouski J, Martha Júnior GB (2015) Integração lavoura-pecuária e integração lavoura-pecuária-floresta: estratégias para intensificação sustentável do uso do solo. Cader Cienc Tecn. 32 (1-2): 15 53.

Costa RRGF, Costa KAP, Santos CB, Severiano EC, Epifânio PS, Silva JT, Silva VR (2016) Production and nutritional characteristics of pearl millet and Paiaguas palisadegrass under different forage systems and sowing periods in the offseason. Afr J Agric Res. 11(19): 1712 - 1723.

Crusciol CAC, Nascente AS, Mateus GP, Pariz CM, Martins PO, Borghi E (2014) Intercropping soybean and palisade grass for enhanced land use efficiency and revenue in a no till system. Eur J Agron. (58): 53 - 62.

Embrapa - Empresa Brasileira de Pesquisa Agropecuária (2013) Sistema Brasileiro de Classificação de Solos (3 ed), Rio de Janeiro: CNPS.

Euclides VPB, Montagner DB, Barbosa RA, Vallem CB, Nantes NN (2016) Animal performance and sward characteristics of two cultivars of Brachiaria brizantha - BRS Paiaguás and BRS Piatã. R Bras Zootec. 45(3): 85 - 92.

Ferreira EB, Cavalcanti PP, Nogueira, DA (2014) ExpDes: An R Package for ANOVA and Experimental Designs. Appl Math. 5: 2952 - 2958.

Gimenes MJ, Victoria Filho R, Prado EP, Pogetto MHFAD, Christovam RS (2008) Interferência de espécies forrageiras em consórcio com a cultura do milho. Revista da FZ VA. (15): 61 - 76.

Guarnieri A, Costa KAP, Severiano EC, Silva AG, Oliveira SS, Santos CB (2019) Agronomic and productive characteristics of maize and Paiaguas palisadegrass in integrated production systems. Semin Cienc Agrar. 40(3): 1185-1198.

Horvathy Neto A, Silva AG, Teixeira IR, Simon GA, Assis RL, Rocha VS (2012) Consórcio sorgo e braquiária para produção de grãos e biomassa na entressafra. Rev Bras Ciênc Agrárias. 7: 743-749.

Machado LAZ, Valle CB (2011) Desempenho agronômico de genótipos de capim braquiária em sucessão à soja. Pesq Agropec Bras. 46(11): 1454 - 1462.

Mertens DR (2002) Gravimetric determination of amylasetreated neutral detergent fiber in feeds with refluxing in beaker or crucibles: collaborative study. J AOAC Int. 85: 1217-1240.

Pacheco LP, Pires FR, Monteiro FP, Procópio SO, Assis RL, Carmo ML, Petter FA (2008) Desempenho de plantas de cobertura em sobressemeadura na cultura da soja. Pesq Agropec Bras. 43(7): 815 - 823.

Ribeiro MG, Costa KAP, Silva AG, Severiano EC, Simon GA, Cruvinel WS, Silva JT (2015) Grain sorghum intercropping with Brachiaria brizantha cultivars in two sowing systems as a double crop. Afr J Agric Res. 10(39): 3759 - 3766.

Ribeiro MG, Costa KAP, Souza WF, Cruvinel WS, Silva JT, Santos Júnior DR (2017) Silage quality of sorghum and Urochloa brizantha cultivars monocropped or intercropped in different planting systems. Acta Sci Anim Sci. 39(3): 243 - 250.

Santos CB, Costa KAP, Oliveira IP, Severiano EC, Costa RRGF, Silva AG, Silva JT (2016) Production and nutritional characteristics of sunflowers and Paiaguas palisadegrass under different forage systems in the off season. Biosci J. 32(2): $460-470$.

Silva AG, Moraes LE, Horvathy Neto A, Teixeira IR, Simon GA (2013) Consórcio na entrelinha de sorgo com braquiária na safrinha para produção de grãos e forragem. Semin Cienc Agrar. 34(6): 3475 - 3488.

Silva AG, Moraes LE, Horvathy Neto A, Teixeira IR, Simon GA (2014) Consórcio sorgo e braquiária na entrelinha para produção de grãos, forragem e palhada na entressafra. Rev Ceres. 61(5): 697 - 705.

Silva AG, Harvathy Neto A, Teixeira IR, Costa KAP, Braccini AL (2015a) Seleção de cultivares de sorgo e braquiária em consórcio para produção de grãos e palhada. Semin Cienc Agrar. 36(5): 2951 - 296.

Silva AG, Francischini R, Goulart MMP (2015b) Desempenho agronômico e econômico de híbridos de sorgo granífero na safrinha em Montividiu-Go. Rev Agricultura. 90(1): 17 -30.

Silva AG, Andrade CLL, Goulart MMP, Teixeira IR, Simon GA, Moura ICS (2017) Consórcio de sorgo granífero e braquiárias na safrinha para produção de grãos e biomassa. Rev Bras Milho Sorgo.16: 495 - 508. 
Silva RO, Barioni LG, Pellegrino GQ, Moran D (2018) The role of agricultural intensification in brazil's nationally determined contribution on emissions mitigation. Agric Syst.161: 102 112.

Soares $A B$, Sartor LR, Adami PF, Varella AC, Fonseca L, Mezzalira JC (2009) Influência da luminosidade no comportamento de onze espécies forrageiras perenes de verão. R Bras Zootec. 38(3): 443 - 451.

Stumpf L, Pauletto EA, Pinto LFS, Pinto MAP, Dutra Junior LA, Scheunemann T (2016) Sistema radicular da Urochloa brizantha: desenvolvimento e influência nos atributos de um solo degradado. Rev Cient Am Lat, 41(5): 334 - 339.
Tilley JMA, Terry RA (1963) A two stage technique for in vitro digestion of forages crops. J Br Grassl Soc.18: 104 - 111.

Van Soest PJ (1994) Nutritional ecology of the ruminant (2 ed), Ithaca and London: Cornell University Press.

Vilela L, Martha Júnior GB, Macedo MCM, Marchão RL, Guimarães Júnior R, Pulrolnik K, Maciel GA (2011) Sistemas de integração lavoura-pecuária na região do cerrado. Pesq Agropec Bras. 46(10): 1127 - 1138. 